\title{
PENGARUH PELATIHAN KERJA DAN MOTIVASI KERJA TERHADAP KINERJA KARYAWAN PADA BANK XYZ UNIT USAHA ASURANSI
}

\author{
${ }^{1 *}$ Rachmawaty, ${ }^{2}$ Fitri Wahyuni \\ Universitas Pamulang, Tangerang, Banten, Indonesia \\ *dosen01925@unpam.ac.id
}

\begin{abstract}
Abstrak
Tujuan dari dilakukan nya penelitian ini adalah untuk mengetahui pengaruh yang diberikan Pelatihan Kerja dan Motivasi Kerja terhadap Kinerja karyawan baik secara parsial maupun simultan pada Bank XYZ. Metode penelitian yang penulis gunakan adalah metode deskriptif dengan pendekatan kuantitatif menggunakan Regresi Linier Berganda. Penelitian dilakukan pada Bank XYZ sebagai objek penelitiannya. Populasi yang digunakan adalah seluruh karyawan Bank XYZ. Berdasarkan hasil penelitian secara parsial (Uji t) disimpulkan bahwa Pelatihan Kerja dan motivasi kerja secara parsial berpengaruh signifikan terhadap Kinerja Karyawan. Berdasarkan uji regresi secara simultan (Uji F) dihasilkan variabel Pelatihan Kerja (X1) dan Motivasi Kerja (X2) berpengaruh signifikan terhadap Kinerja Karyawan $(Y)$. Dengan persentase secara simultan adalah $80.3 \%$ dan persamaan Regresi Linier Berganda adalah $Y=0,792$ X1 + 0,229 X2 + 1,782.
\end{abstract}

Kata Kunci: Pelatihan Kerja, Motivasi Kerja, Kinerja Karyawan, Regresi Linier Berganda

\section{Abstract}

The purpose of this research is to determine the effect of job training and work motivation on employee performance either partially or simultaneously in the Telemarketing division at Bank XYZ. The research method was a descriptive method with a quantitative approach and uses Multiple Linear Regression.

The research was conducted at Bank XYZ - Telemarketing Division. The population used is all employees of Bank $X Y Z-$ Telemarketing Division. Based on the results of research partially ( $t$ test) it was concluded that job training and work motivation partially significant effect on employee performance, with a positive relationship direction. Based on the simultaneous regression test (Test F), the variable job training (X1) and work motivation (X2) have a significant effect on employee performance $(Y)$. With the simultaneous percentage is $80,3 \%$ and the Multiple Linear Regression equation is $Y=0.792 X 1+0.229$ X2 +1.782 .

Keywords: Job Training, Work Motivation, Employee Performance, Multiple Linear Regression

\section{PENDAHULUAN}

Bank XYZ unit usaha Asuransi merupakan perusahaan asuransi yang menyediakan berbagai produk asuransi seperti Asuransi Kehidupan (Jiwa), Kesehatan, Pendidikan, Investasi, Pensiun dan Syariah. Pendirian Bank XYZ Unit Usaha Asuransi, sejalan dengan kebutuhan perusahaan induknya, Bank XYZ, untuk menyediakan layanan dan jasa keuangan terpadu bagi semua nasabahnya (one-stop financial services). Saat ini Bank XYZ telah hadir melalui 4 saluran distribusi yaitu Agency, Bancassurance, Employee Benefits dan Syariah. Agency dipasarkan melalui agen-agen yang memasarkan produk individu, sedangkan Bancassurance

dipasarkan melalui jaringan Bank XYZ di seluruh Indonesia. Employee Benefits dikhususkan bagi produk-produk asuransi kumpulan ke perusahaan-perusahaan, sedangkan syariah memasarkan produk asuransi baik individu, ataupun kumpulan dengan prinsip syariah.

Dalam perusahaan ini yang menjadi hal penting adalah karyawan lapangan yaitu karyawan yang langsung terjun pada pekerjaan seperti Bancassurance atau Agancy dan telemarketing online, karyawan lapangan adalah karyawan yang paling dekat dengan pelanggan dan berpengaruh terhadap pelanggan. Direktur Utama mengungkapkan masalah yang 
dihadapi oleh perusahaan adalah pengelolaan sumber daya manusia khususnya karyawan lapangan. Dalam perusahaan kurang adanya pelatihan yang baik kepada karyawan lapangan menjadikan karyawan melakukan banyak kesalahan yang akan berakibat terjadinya miskomunikasi pada presentasi atau penyampaian manfaat produk atau bahkan tentang produk itu sendiri kepada calon nasabah Bank XYZ, sehingga calon nasabah menjadi kurang puas atau kurang yakin dengan jasa yang diberikan oleh perusahaan.

Ditegaskan Dirut kurangnya pelatihan yang buruk berdampak pada adanya ketidak yakinan nasabah terhadap suatu produk yang di presentasikan bahwa adanya hubungan yang proporsional antara pelatihan dengan kinerja karyawan.

Di sisi lain, menurut Direktur Utama Bank XYZ juga mengalami masalah pada motivasi kerja karyawan. Karyawan pada Bank XYZ kurang termotivasi sehingga diduga pekerjaan tidak tepat pada waktu yang ditentukan oleh perusahaan. Hal tersebut menjadikan calon nasabah menjadi kurang terpuaskan terkait penyampaian produk yang di informasikan. Karyawan cenderung terlalu santai dalam mengerjakan pekerjaannya karena kurangnya motivasi atau bahkan sudah merasa puas pada diri karyawan tersebut. Bank XYZ Jakarta mengalami masalah dalam motivasi kerja pada dalam diri karyawan yang berakibat pada kinerja karyawan yang menyebabkan muncul ketidak yakinan atas program atau produk yang disampaikan oleh karyawan tersebut.

Diberikan oleh perusahaan. melalui pelatihan dan motivasi akan berpengaruh pada

peningkatan kinerja karyawan. Dengan motivasi yang kuat, serta pelatihan yang maksimal diharapkan kinerja yang dihasilkan karyawan dapat meningkat sehingga tujuan atau harapan perusahaan dapat tercapai. Meskipun melalui pelatihan dan motivasi dapat meningkatkan kinerja karyawan tetapi pada kenyataannya masih ada
Perusahaan yang mengalami masalah pada kurang efektifnya pelatihan dan kurang

tingginya motivasi bekerja hal tersebut terjadi pada Bank XYZ. Adapun aspek-aspek standar kinerja menurut Mangkunegara terdiri dari aspek kuantitatif dan aspek kualitatif. Aspek kuantitatif meliputi: proses kerja dan kondisi pekerjaan, waktu yang dipergunakan atau lamanya melaksanakan pekerjaan, jumlah kesalahan dalam melaksanakan pekerjaan, dan jumlah dan jenis pemberian pelayanan dalam bekerja Sedangkan aspek kualitatif meliputi: ketepatan kerja dan kualitas pekerjaan, tingkat kemampuan dalam bekerja, kemampuan menganlisis data/informasi, kemampuan/kegagalan menggunakan mesin/peralatan, kemampuan mengevaluasi (keluhan/konsumen).

Masalah sumber daya manusia menjadi sorotan dan tumpuan bagi perusahaan

untuk tetap dapat bertahan di era globalisasi. Sumber daya manusia mempunyai peran utama dalam setiap kegiatan perusahaan. Dalam rangka meningkatkan kinerja karyawan Bank XYZ di harapkan pelatihan yang di laksanakan dapat lebih meningkatkan prestasi kinerja karyawan. Prestasi kinerja karyawan salah satu kegiatan yang sangat di perhatikan karena tenaga kerja dapat menghasilkan berbagai pembelajaran yang mengarah pada kemajuan kinerja karyawan pada Bank XYZ Rendahnya motivasi kerja sangat di pengaruhi oleh perhatian pemimpin terhadap pemberdayaan sumber daya manusia (SDM), dalam meningkatkan profesionalisme. Penelitian ini mengambil objek pada Bank XYZ yang berada di Jl. Gatot subroto Centennial Tower kav 24 dan 25 Jakarta Selatan, Daerah Khusus Ibu Kota Jakarta 12930

Berdasarkan hasil uraian di atas, penulis tertarik untuk membahas lebih lanjut dan

memilih Manajemen Sumber Daya Manusia sebagai subjek penelitian dan Bank XYZ sebagai objek penelitian, maka 
penelitian ini berjudul " Pengaruh Motivasi

Kerja dan Pelatihan Terhadap Kinerja

Karyawan Pada. Bank XYZ “

Tabel 1 Data absensi karyawan Bank XYZ (cabang pancoran)

\begin{tabular}{|c|c|c|c|c|c|c|}
\hline \multirow{2}{*}{ No. } & \multirow{2}{*}{ Bulan } & \multirow{2}{*}{$\begin{array}{c}\text { Jumlah } \\
\text { karyawan }\end{array}$} & \multicolumn{3}{|c|}{ Absensi } & \multirow{2}{*}{ Jumlah } \\
\hline & & & Alfa & Ijin & Sakit & \\
\hline 1 & Januari & 200 & 5 & 3 & 2 & 10 tidak hadir \\
\hline 2 & Februari & 200 & 1 & 3 & 4 & 8 tidak hadir \\
\hline 3 & Maret & 200 & 8 & 2 & 4 & 14 tidak hadir \\
\hline 4 & April & 200 & 3 & 0 & 5 & 8 tidak hadir \\
\hline 5 & Mei & 200 & 2 & 5 & 2 & 9 tidak hadir \\
\hline 6 & Juni & 200 & 1 & 7 & 8 & 16 tidak hadir \\
\hline 7 & Juli & 200 & 3 & 3 & 0 & 6 tidak hadir \\
\hline 8 & Agustus & 200 & 7 & 1 & 8 & 16 tidak hadir \\
\hline 9 & September & 200 & 3 & 7 & 4 & 14 tidak hadir \\
\hline 10 & Oktober & 200 & 6 & 6 & 6 & 18 tidak hadir \\
\hline 11 & November & 200 & 7 & 6 & 1 & 14 tidak hadir \\
\hline 12 & Desember & 200 & 6 & 2 & 2 & 10 tidak hadir \\
\hline
\end{tabular}

Sumber: Bank XYZ (2018)

Tabel di atas menunjukan tingkat ketidak kehadiran karyawan selama 12 bulan, dari bulan Januari - Desember 2018, bisa dilihat jumlah karyawan yang tidak semakin meningkat dari setiap bulannya, hal ini bila tidak segera di lakukan tindakan maka akan berdampak buruk bagi pencapaian

tujuan perusahaan untuk itu pemimpin perusahaan harus lebih memperhatikan pemberian motivasi yang ada di perusahaan agar karyawan dapat kembali bersemangat bekerja dan menunjukan kinerja yang baik dalam membantu tercapainya tujuan perusahaan.

Tabel 2 Data pelatihan karyawan Bank XYZ (cabang pancoran)

\begin{tabular}{|c|c|c|c|}
\hline No. & Bulan & Jenis Pelatihan & Peserta Pelatihan \\
\hline 1 & Januari & Sinergy & 118 \\
\hline 2 & Februari & Value of TSO & 164 \\
\hline 3 & Maret & Value of TSO & 190 \\
\hline 4 & April & Prisai Plus & 138 \\
\hline 5 & Mei & PA Protection Plus & 115 \\
\hline 6 & Juni & Maxi Health CC \&Prisai Plus & 107 \\
\hline 7 & Juli & Maxi Health CC \&PA Protection Plus & 94 \\
\hline 8 & Agustus & Proteksi Prima & 182 \\
\hline 9 & September & Fact Finding \& Create Need & 151 \\
\hline 10 & Oktober & Handling Objection & 104 \\
\hline 11 & November & Bedah Polis Active & 179 \\
\hline 12 & Desember & Sharing Sesion \& Motivation & 128 \\
\hline
\end{tabular}

Sumber: Bank XYZ (cabang pancorang) 2018

Tabel diatas menunjukan kurangnya jumlah karyawan dan di duga masih kurangnya materi pelatihan pada Bank XYZ dari Bulan Januari - Desember 2018, hal ini harus mendapat perhatian dari manajemen perusahaan agar lebih di optimalkan para peserta pelatihan dan menambahkan materi pelatihan yang sesuai ddengan level nya masing masing, agar perusahaan memiliki karyawan yang berkompeten untuk membantu tercapainya tujuan perusahaan.

\section{TINJAUAN PUSTAKA}

1. Pelatihan Kerja

Menurut Widodo (2015:82). pelatihan merupakan serangkaian 
aktivitas individu dalam meningkatkan keahlian dan pengetahuan secara sistematis sehingga mampu memiliki kinerja yang profesional di bidangnya Pelatihan adalah proses pembelajaran yang memungkinkan pegawai melaksanakan pekerjaan yang sekarang sesuai dengan standar.

Disisi lain para peserta pelatihan kurang memahami materi pelatihan yang Disampaikan oleh trainer/instruktur, sehingga peserta pelatihan kurang menguasai materi pelatihan yang di berikan oleh trainer, sehingga akan berdampak buruk bagi perusahaan.

Pelatihan yang baik akan membawa manfaat antara lain yang dikemukakan oleh Noe, Hollenbeck, Gerhart, Wright yaitu: meningkatkan pengetahuan para karyawan atas budaya dan para pesaing luar, membantu para karyawan yang mempunyai keahlian untuk bekerja dengan teknologi baru, membantu para karyawan untuk memahami bagaimana bekerja secara efektif dalam tim untuk menghasilkan jasa yang berkualitas, memastikan bahwa budaya perusahaan menekankan pada inovasi, kreativitas dan pembelajaran, menjamin keamanan dan keselamatan dengan memberikan caracara baru bagi para karyawan untuk memberikan kontribusi bagi perusahaan pada saat pekerjaan dan kepentingan mereka berubah atau pada saat keahlian mereka menjadi absolut. Dan harus jelas di mata para peserta pelatihan. Maksudnya disini adalah job specification yang selanjutnya akan diemban harus dijelaskan terlebih dahulu kepada pekerja. Jadi para peserta pelatihan akan bersungguh sungguh selama mengikuti program pelatihan.

$$
\text { Menurut Widodo (2015:82), }
$$

pelatihan merupakan serangkaian aktivitas individu dalam meningkatkan keahlian dan pengetahuan secara sistematis sehingga mampu memiliki kinerja yang profesional di bidangnya. Berdasarkan pengertian tersebut, pelatihan berarti suatu perubahan yang sistematis dari Knowledge, Skill, Attitude dan Behaviour yang terus mengalami peningkatan yang dimiliki oleh setiap karyawan dengan itu dapat mewujudkan sasaran yang ingin dicapai oleh suatu organisasi atau perusahaan dalam pemenuhan standar SDM yang diinginkan.

Menurut pasal 1 ayat 9 undangundang No. 13 Tahun 2003 Tentang Ketenagakerjaan pelatihan kerja adalah keseluruhan kegiatan untuk memberi, memperoleh, meningkatkan serta mengembangkan

kompetensi kerja, produktifitas, disiplin, sikap, dan etos kerja pada tingkat keterampilan dan keahlian tertentu sesuai dengan jenjang dan kualifikasi jabatan dan pekerjaan.

Menurut Veithzal Rivai (2014:173) dalam melakukan pelatihan adabeberapa faktor yang mempengaruhi yaitu instruktur, peserta, materi (bahan), metode, tujuan pelatihan, dan lingkungan yang menunjang. Metode pelatihan terbaik tergantung dari berbagai faktor. Faktor-faktor yang perlu dipertimbangkan dalam pelatihan yaitu:

1. Cost-Efectiveness atau Efektivitas biaya

2. Materi progam yang dibutuhkan 30

3. Prinsip-prinsip pembelajaran

4. Ketepatan dan kesesuaian fasilitas

5. Kemampuan dan preferensi peserta pelatihan

6. Kemampuan dan preferensi instruktur pelatihan

Beberapa pendapat para ahli mengenai definisi pelatihan sebagai berikut:

a) Menurut Sedarmayanti (2013:164) Pelatihan adalah bagian dari pendidikan menyangkut proses belajar untuk memperoleh dan meningkatkan keterampilan diluar system pendidikan yang berlaku, dalam waktu yang relative singkat dan dengan metode yang lebih mengutamakan praktek dari pada teori. 
b) Biech dalam Priansa (2014:176) juga menyatakan bahwa, "Pelatihan adalah tentang perubahan, tenatang transformasi, tentang pembelajaran. Pelatihan adalah proses yang dirancang untuk membantu pegawai mempelajariketerampilan,

pengetahuan, atau sikap baru. Akibatnya, pegawai tersebut akan membuat perubahan atau transformasi yang akan meningkatkan kinerjanya."

c) Menurut Sjafri Mangkuprawira dalam Yani (2012:82) menambahkan bahwa, "Pelatihan bagi karyawan merupakan sebuah proses mengajarkan pengetahuan dan keahlian tertentu serta sikap agar karyawan semakin terampil dan mampu melaksanakan tanggung jawabnya dengan semakin baik, sesuai dengan standar.

Dari beberapa definisi yang diuraikan diatas, maka dapat ditarik kesimpulan bahwa pelatihan adalah proses mengajarkan keterampilan bagi pegawai diluar system pendidikan yang berlaku dengan tujuan untuk meningkatkan keterampilan yang dimiliki pegawai.

2. Motivasi Kerja

Menurut Malayu Hasibuan S.P (2017:141), Motivasi berasal dari kata latin movere yang berarti dorongan atau menggerakkan. Motivasi dalam manajemen hanya ditujukan pada sumber daya manusia umumnya dan bawahan khususnya. Motitvasi mempersoalkan bagaimana caranya mengarahkan daya dan potensi bawahan agar mau bekerja sama secara produktif berhasil mencapai dan mewujudkan tujuan yang ditentukan.

Menurut Azwar (2017:73), motivasi merupakan rangsangan dorongan ataupun pembangkit tenaga yang dimiliki seseorang atau sekelompok masyarakat yang mau berbuat dan bekerjasama secara optimal dalam melaksanakan sesuatu yang telah direncanakan untuk mencapai tujuan yang telah ditetapkan.

Menurut Hamalik (2017:173) motivasi merupakan energi dalam diri atau pribadi seseorang yang ditandai dengan timbulnya perasaan dan reaksi untuk mencapai tujuan.

Berdasarkan definisi di atas, dapat diketahui bahwa motivasi merupakan kekuatan yang menggerakan perilaku yang memberi arah pada perilaku dan mendasari kecenderungan untuk tetap menunjukkan perilaku tersebut.

Kedisiplinan merupakan fungsi operasional manajemen sumber daya manusia yang terpenting karena semakin baik disiplin kerja pegawai, semakin baik kinerja yang dapat dicapai. Tanpa disiplin yang baik, sulit bagi organisasi untuk mencapai hasil yang optimal. Kedisiplinan merupakan faktor yang utama yang diperlukan sebagai alat peringatan terhadap pegawai yang tidak mau berubah sifat dan perilakunya. Sehingga seorang pegawai dikatakan memiliki disiplin yang baik jika pegawai tersebut memiliki rasa tanggung jawab terhadap tugas yang diberikan kepadanya.

Berikut adalah pengertianpengertian disiplin kerja menurut para ahli diantaranya yaitu:

Menurut Hasibuan (2006:444) bahwa: "Disiplin kerja adalah kesadaran dan kerelaan seseorang dalam menaati semua peraturan perusahaan dan norma-norma sosial yang berlaku."

Menurut Rivai (2011:825) bahwa: "Disiplin kerja adalah suatu alat yang dipergunakan para manajer untuk berkomunikasi dengan karyawan agar mereka bersedia untuk mengubah suatu perilaku serta sebagai suatu upaya untuk meningkatkan kesadaran dan kesedian seorang dalam memenuhi segala peraturan perusahaan."

3. Kinerja Karyawan

Kinerja merupakan suatu upaya yang dilakukan seorang karyawan karena mengacu pada tujuan yang hendak dicapai. Penilaian kinerja 
merupakan proses yang dilakukan organisasi dalam mengevaluasi kinerja pekerjaan sescorang. Apabila hal itu dikerjakan dengan benar oleh karyawan maka organisasi atau perusahaan akan menguntungkan dengan jaminan bahwa upaya para karyawan mampu mengkontribusikan pada fokus strategik dari perusahaan atau organisasi

a. Menurut Rivai dan Basri dalam Bintoro dan Daryanto (2017:106) Kinerja adalah hasil atau tingkat keberhasilan seseorang secara keseluruhan selama periode tertentu dalam melaksanakan tugas dibandingkan dengan berbagni keruungkinan, seperti standar hasil kerja, target atau sasaran dan kinerja yang telah ditentukan terlebih dahulu telah disepakati bersama

b. Menurut Mangkunegara mengemukakan bahwa kinerja SDM adalah prestasi kerja atau hasil kerja (output) baik kualitas maupun kuantitas yang dicapai SDM persatuan periode waktu $\mathrm{dm}$ clahtunakan tugas ketjanya sesua dengan tanggung jawab yang diberikan kepadanya

\section{METODE}

Penelitian ini dilaksanakan di Bank XYZ Cabang pancorang yang ber alamat. SHE Tower, Jl. Gatot Subroto No.94, RT.11/RW.3, Pancoran, Kec. Pancoran, Kota Jakarta Selatan, Daerah Khusus Ibukota Jakarta 12780 . Waktu Penelitian ini dilaksanakan selama 3 (Tiga) bulan yang dimulai dari bulan Oktober 2020 sampai Desember 2020 Populasi dalam penelitian populasinya ,Teknik pengumpulan data menggunakan kuisioner kepada seluruh pegawai Bank XYZ cabang Pancoran.

\section{HASIL DAN PEMBAHASAN}

1. Pembahasan Hasil Penelitian

Berdasarkan hasil penelitian yang telah diuraikan sebelumnya menunjukkan bahwa terdapat pengaruh positif dan signifikan baik secara parsial (Uji t) disimpulkan bahwa Pelatihan Kerja dan motivasi kerja secara parsial berpengaruh signifikan terhadap Kinerja Karyawan

a. Pengaruh Pelatihan $\left(X_{1}\right)$ Terhadap Kinerja karyawan $(Y)$

Berdasarkan hasil penelitian ini didapatkan bahwa variable Pelatihan $\left(X_{1}\right)$ memiliki pengaruh terhadap Kinerja (Y) pada karyawan Bank XYZ Cabang Pancoran diperoleh ratarata skor sebesar 4 dengan kriteria setuju. Responden yang memberikan penilaian sangat setuju dan setuju sebesar $76 \%$ dan responden yang menjawab kurang setuju, tidak setuju dan sangat tidak setuju sebesar $24 \%$.

Hasil penelitian ini, diperoleh nilai persamaan regresi $\mathrm{Y}=19.222+$ 0.529 X1 koefisien korelasi sebesar 0.589 artinya kedua variabel mempunyai tingkat pengaruh yang sedang. Uji hipotesis diperoleh nilai $\mathrm{t}$ hitung $>\mathrm{t}$ tabel atau $(6.685>1.989)$, hal ini diperkuat dengan probability significancy $0.000<0.05$, dengan demikian $\mathrm{H} 0$ ditolak dan $\mathrm{H} 1$ diterima artinya terdapat pengaruh yang signifikan secara parsial antara Pelatihan terhadap Kinerja karyawan

b. Pengaruh Motivasi kerja $\left(X_{2}\right)$ Terhadap Kinerja karyawan (Y)

Berdasarkan hasil pengujian hipotesis pertama yang telah dilakukan, didapatkan bahwa variable Motivasi Kerja (X2) memiliki pengaruh terhadap Kinerja Karawan (Y) pada Bank XYZ cabang pancoran

Pengaruh Motivasi kerja dapat dilihat dari faktor pada pernyataan nomor 2 dan 4 yaitu Gaji yang diterima sesuai dengan harapan dan Bonus yang saya terima sudah sesuaiharapan dimana masing masing dari indikator tersebut sama sama hanya mencapai score 3,6. Hal ini berarti gaji sangat berperan penting dalam motivasi kerja pada karyawan. Hasil 
pengujian ini sejalan dengan beberapa penelitian terdahulu.

Hasil penelitian ini, diperoleh nilai persamaan regresi $\mathrm{Y}=0,792 \mathrm{X} 1+0,229$ $\mathrm{X} 2+1,782$. koefisien korelasi sebesar 0,879 artinya kedua variabel mempunyai tingkat pengaruh yang kuat. Uji hipotesis diperoleh nilai t hitung sebesar 3.161>1.99773 hal ini menunjukan bahwa Motivasi karyawan berpengaruh terhadap Kinerja Karyawan. dengan demikian $\mathrm{H} 0$ ditolak dan $\mathrm{H} 2$ diterima artinya terdapat pengaruh yang signifikan secara parsial antara Motivasi kerja terhadap Kinerja karyawan Bank XYZ Cabang Pancoran. Pengaruh Pelatihan $\left(X_{1}\right)$ dan Motivasi kerja (X2) Secara Simultan Terhadap Kinerja karyawan (Y)

Hasil penelitian ini menunjukkan bahwa Pelatihan (X1) dan Motivasi kerja (X2) berpengaruh positif terhadap Kinerja karyawan $(\mathrm{Y})$.

\section{PENUTUP}

\section{Simpulan}

Berdasarkan hasil penelitian yang telah dilakukan untuk mengetahui pengaruh Pelatihan Kerja dan Motivasi kerja terhadap Kinerja Karyawan pada Bank XYZ Cabang Pancoran, dapat disimpulkan sebagai berikut:

1. Secara parsial (sendiri-sendiri) terdapat pengaruh signifikan Pelatihan Kerja dan Motivasi Kinerja terhadap Kinerja Karyawan pada Bank XYZ.

2. Terdapat pengaruh signifikan secara Bersama (simultan) Pelatihan Kerja dan Motivasi Kerja terhadap Kinerja Karyawan pada Bank XYZ.

Dari Hasil Uji Koefisien Regresi Berganda penulis menyimpulkan bahwa terdapat hubungan positif yang terjadi antara Pelatihan Kerja dan Motivasi Kerja terhadap Kinerja Karyawan. Hasil Uji Koefisien Determinasi menunjukan bahwa secara simultan pengaruh dari Pelatihan Kerja dan Motivasi Kerja terhadap Kinerja Karyawan adalah 80,3\% Dengan model $\mathrm{Y}=$ $0,792 X 1+0,229$ X2 + 1,782. dimana Y adalah Kinerja Karyawa, X1 adalah Pelatihan Kerja dan X2 adalah Motivasi Kerja.
Secara keseluruhan tanggapan responden atas pernyataan pada variabel Pelatihan Kerja $\left(X_{1}\right)$ diperoleh rata-rata skor sebesar 4 dengan kriteria setuju. Responden yang memberikan penilaian sangat setuju dan setuju sebesar $76 \%$ dan responden yang menjawab kurang setuju, tidak setuju dan sangat tidak setuju sebesar $24 \%$.

Secara keseluruhan tanggapan responden atas pernyataan pada variabel Motivasi Kerja $\left(X_{2}\right)$ diperoleh rata-rata skor sebesar 4 dengan kriteria setuju. Responden yang memberikan penilaian sangat setuju dan setuju sebesar $69 \%$ dan responden yang menjawab kurang setuju, tidak setuju dan sangat tidak setuju sebesar $31 \%$.

Secara keseluruhan tanggapan responden atas pernyataan pada variabel Kinerja Karyawan (Y) diperoleh rata-rata skor sebesar 4 dengan kriteria setuju.

\section{Saran}

1. Variabel pelatihan kerja, indikator yang paling lemah adalah pada pernyataan nomor 8 yaitu Tujuan pelatihan tercapai antara lain pelatihan membantu peserta bekerja dengan efektif dan efisiendimana hanya mencapai score 3,7. Untuk lebih baik lagi perusahaan harus melakukan evaluasi materi pelatihan agar dapat memberikan solusi sesuai dengan tingkat kesulitan atau kendala yang dialami oleh karyawan agar memenuhi kerangka pencapaian tujuan organisasi yang lebih maksimal. Evaluasi tujuan pelatihan dilakukan secara berkala sehingga diperoleh hasil umpan balik yang terus menerus untuk membantu peserta bekerja secara effektif dan effisien dalam pekerjaannya.

2. Variabel Motivasi Kerja , indikator yang paling lemah adalah pada pernyataan nomor 2 dan 4 yaitu Gaji yang diterima sesuai dengan harapan dan Bonus yang saya terima sudah sesuaiharapan dimana masing masing dari indikator tersebut sama sama hanya mencapai score 3,6. Saran untuk point tersebut adalah perusahaan dapat melakukan evaluasi struktur gaji atau tunjangan dan bonus sesuai dengan benchmark di 
industry perbankan. Struktur gaji, tunjangan dan bonus juga memperhatikan kinerja karyawan yang berprestasi sehingga karyawan akan lebih termotivasi untuk memberikan kinerja terbaik kepada perusahaan.

3. Variabel Kinerja Karyawan, indikator yang paling lemah adalah pada pernyataan nomor 10 yaitu Pemberian imbalan meningkatkan kinerja perusahaan dan berdampak kepada peningkatan keuntungan perusahaan dimana hanya mencapai score 3,8. Saran perbaikan untuk point tersebutperusahaan harus memberikan reward atau imbalan sesuai dengan hasil yang di berikan dengan karyawan sesuai dengan standarnya agar, karyawan juga merasa nyaman hingga memberikan konturibusi yang lebih untuk kedepannya untuk perusahaan tersebut.

4. Pengaruh pelatihan kerja dan motivasi kerja secara simultan terhadap kinerja karyawan memberikan kontribusi sebesar 80,3\%, hal ini menunjukkan bahwa terdapat faktor lain selain 2 faktor tersebut. Oleh karenanya disarankan kepada penelitian berikutnya agar melakukan penelitian dengan menambahkan factor pengaruh lainnya.

\section{DAFTAR PUSTAKA}

Andrew E. Sikula. (2011). Manajemen Sumber Daya Manusia, Erlangga.Bandung. Aditama. Jakarta.

Balkin, dan Cardy, (2011), Human Resource Management, Edisi kedua, Refika

Barry,Cushway. (2012), Human Resource Management, Jakarta: PT.Gramedia.

Bumi Aksara.

Dessler, Gary (2015). Human Resources Management (Manajemen Sumber Daya Manusia), Ed. 14. Edisi Bahasa Indonesia. Jakarta: Salemba empat jakarta.

Edwin B.Flippo, (2010) Pelatihan Kerja, Edisi VII jilid II,Terjemahan Alponso S, Erlangga, Jakarta.

Edwin B.Flippo, (2010) Pelatihan Kerja, Edisi VII jilid II, Terjemahan Alponso S, Erlangga, Jakarta.
Effendi Sinuhaji (2014) Pengaruh Kepribadian, Kemampuan Kerja dan Motivasi Kerja terhadap Kinerja SDM Outsourcing pada PT. Catur Karya Sentosa Medan, Jurnal Ilman, Vol. 1(1), No 2355-1488

Ghozali, Imam. (2011). Aplikasi Analisis Multivariate dengan Program IBM SPSS 21 Update PLS Regresi. Semarang:BadanPenerbit Universitas Diponegoro.

Hasibuan, Malayu S.P (2009). Manajemen Sumber Daya Manusia. Edisi Revisi. Jakarta: PT Bumi Aksara

Hasibuan, Malayu S.P., (2011). Manajemen Sumber Daya Manusia. Bumi Aksara, Jakarta

I Wayan Sutya Edy Kumara, I Wayan Mudiartha Utama (2016) Pengaruh Pelatihan Terhadap Kinerja Karyawan Dengan Mediasi Kepemimpinan Pada Hotel Satriya Cottages Kuta - Bali, E-Jurnal Manajemen Unud, Vol. 5(3), No 13991428

Indra Marjaya1, Fajar Pasaribu (2019) Pengaruh Kepemimpinan, Motivasi, Dan Pelatihan Terhadap Kinerja Pegawai, Jurnal Ilmiah Magister Manajemen, Vol 2(1), No 129-147

Mangkunegara, A.A Anwar Prabu. (2014). Evaluasi Kinerja SDM. Bandung: Penerbit Rafika Aditama

Mangkunegara, Prabu Anwar A.A. (2015). "Manajemen Sumber Daya Manusia Perusahaan". Bandung: PT. Remaja Rosdakarya

Mathis, Robert L dan Jackson John H. (2006). Human Resources Management, alih bahasa. Jakarta; Salemba Empat

Tika, Moh. Pabundu. (2012). Budaya organisasi dan peningkatan kinerja perusahaan. Jakarta: BumiAksara

Robbins, Stephen P. (2011) Penilaian Kinerja dan pengembangan karyawan. Cetakan kelima, BPPE-Yogyakarta, Yogyakarta.

Sedarmayanti. (2011). Manajemen Sumber Daya Manusia, Reformasi Birokrasi Manajemen Pegawai Negeri Sipil. Bandung : Rafika Aditama 
Sedarmayanti. (2013). Manajemen Sumber Daya Manusia. Bandung : PT Refika Aditama.

Sugiyono. (2011). "Metode Penelitian Kuantitatif Kualitatif R\&D". Bandung : CV. Alfabeta.

Widodo. (2015). Manajemen Pengembangan Sumber Daya Manusia. Pustaka Pelajar, Yogyakarta.
Yani, M.(2012). Manajemen Sumber Daya Manusia. Jakarta; Mitra Wacana Media.

Zameer, H., Ali, S., Nisar, W., Amir, M. (2014, January). The impact of the motivation on the employee's performance in beverage industry of Pakistan. International Journal of Academy Research in Accounting, Finance \& Management Sciences, 4(1), 293-298. 